\title{
Challenges of Diagnosing Antibody-Mediated Rejection: The Role of Invasive and Non-Invasive Biomarkers
}

\author{
Sambhavi Krishnamoorthy * and Yousuf Kyeso * \\ Division of Nephrology, The University of Chicago Medical Center, Chicago, IL 60637, USA \\ * Correspondence: samk@medicine.bsd.uchicago.edu (S.K.); kyeso1@medicine.bsd.uchicago.edu (Y.K.)
}

\begin{abstract}
Kidney transplantation is the best treatment modality for end-stage kidney disease, leading to improvement in a patient's quality and quantity of life. With significant improvements in shortterm outcomes, prolonging long-term allograft and patient survival remain ongoing challenges. The ability to monitor allograft function, immune tolerance and predict rejection accurately would enable personalization and better prognostication during post-transplant care. Though kidney biopsy remains the backbone of transplant diagnostics, emerging biomarkers can help detecting kidney allograft injury early enough to prevent permanent damage and detect injury before it is clinically apparent. In this review, we summarize the recent biomarkers that have shown promise in the prediction of acute rejection with a focus on antibody-mediated rejection in kidney transplantation.
\end{abstract}

Keywords: kidney transplantation; antibody-mediated rejection; biomarkers

Citation: Krishnamoorthy, S.; Kyeso,

Y. Challenges of Diagnosing

Antibody-Mediated Rejection: The Role of Invasive and Non-Invasive Biomarkers. Medicina 2021, 57, 439. https://doi.org/10.3390/medicina 57050439

Academic Editors: Pradeep

V. Kadambi and W James Chon

Received: 12 March 2021

Accepted: 23 April 2021

Published: 3 May 2021

Publisher's Note: MDPI stays neutral with regard to jurisdictional claims in published maps and institutional affiliations.

Copyright: (c) 2021 by the authors. Licensee MDPI, Basel, Switzerland. This article is an open access article distributed under the terms and conditions of the Creative Commons Attribution (CC BY) license (https:// creativecommons.org/licenses/by/ $4.0 /)$.

\section{Introduction}

In the current era of kidney transplantation, one-year patient and allograft survival exceed 95\% [1]. Though a comparison of older cohorts of kidney transplant recipients to recent cohorts shows improving long-term outcomes, five-year patient and allograft survival continue to lag behind [2]. Advances in immunosuppression strategies, that have led to a decline in the incidence of acute rejection in the early postoperative period, are a major factor behind the remarkable short-term outcomes. However, antibody-mediated rejection (ABMR) continues to be a crucial factor in poor long-term graft survival and could present many years after transplantation [3-5].

The presence of pre-existing or de novo donor-specific antibodies (DSA), histologic evidence of glomerular injury and microcirculatory inflammation that have been implicated in development of transplant glomerulopathy and/or late kidney allograft failure are antibody-mediated processes [6-10]. Loupy et al. described the continuum of antibodymediated damage, varying from an indolent process to functionally significant ABMR, leading to varying degrees of acute and chronic damage and eventual graft loss [11-14].

Though we are making major advances in understanding the pathophysiology and immunology of ABMR, we continue to rely on traditional markers like creatinine, proteinuria and kidney biopsy for screening and definitive diagnosis. Kidney biopsy, which is the gold standard to diagnose and differentiate between types of rejection and pathologic processes, is invasive, can have complications and is costly. Kidney biopsy is also subject to sampling error and interobserver variability between pathologists and different transplant centers [15]. Markers such as creatinine and DSAs may not be elevated until the disease process has reached an advanced stage and miss the window of treating an early subclinical rejection, which can impact long-term graft outcome [16].

Prior reviews have comprehensively described how the expansion of the "omics" field has led to a new era of transplant biomarkers which could be predictive, diagnostic or prognostic $[17,18]$. Biomarkers depending on the source could be invasive, as in requiring a tissue sample of the allograft, or be non-invasively obtained from blood or urine samples [19]. We review the current literature on potential biomarkers in the setting of 
ABMR from a diagnostic perspective with an emphasis on donor-derived cell-free DNA (dd-cfDNA) and molecular microscopy techniques (Figure 1).

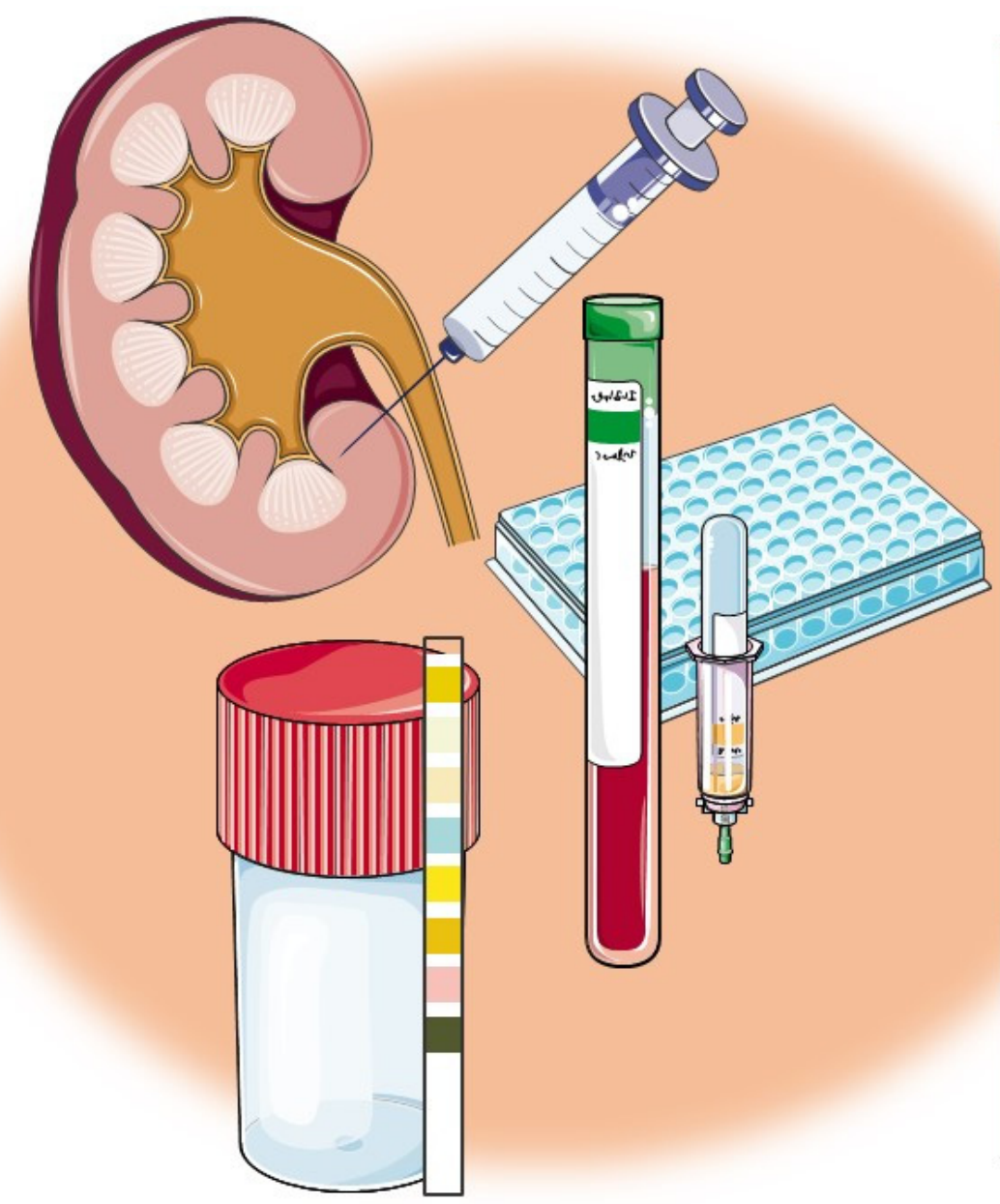

Invasive Biomarkers
Kidney Biopsy
Nolectlar Microscopy
Blood
Donor-specific antibodies
Donor-derived cell free DNA
TruGraf assay
Non-HLA antibodies
Peripheral blood gene/ mRNA arrays
Urine
Chemokines

Figure 1. Overview of invasive and non-invasive biomarkers reviewed in this article.

\section{Invasive Biomarkers}

\subsection{Kidney Biopsy-Banff Classification}

Histologic evaluation via a kidney biopsy remains the gold standard of differentiating T cell-mediated rejection (TCMR) and ABMR. In 1993, the Banff schema was introduced with numeric coding of histologic features to allow for objectivity and definition of grades of acute rejection [20]. ABMR is further defined in the Banff 97 schema, as glomerulitis and peritubular capillaritis in the presence of donor-specific antibody or positive crossmatch [21]. Since then, the diagnosis of ABMR has evolved to acknowledge the recognition of C4d negative ABMR and the significance of non-HLA antibodies in the absence of donor-specific antibodies. The 2017 Banff meeting introduced the molecular analysis of biopsy tissue into the diagnostic algorithm with increased expression of gene transcripts or classifiers as evidence for the interaction of antibody with the allograft endothelium even in the absence of DSA or C4d positivity, as long as it is validated at the transplant center [22].

\subsection{Molecular Microscopy Diagnostic System}

The "molecular microscope diagnostic system" (MMDx) is a microarray-based system that examines messenger RNA (mRNA) expression patterns in transplant biopsy tissue to predict the diagnosis of acute TCMR or ABMR [23]. Halloran et al. and Strom et al. have shown that mRNA levels in a biopsy sample can diagnose specific disease states $[23,24]$. 
The development of MMDx was based upon the findings of several studies in kidney transplant patients that described and were validated for TCMR, ABMR, acute kidney injury (AKI) and interstitial fibrosis/tubular atrophy (IF/TA) $[23,25,26]$. In one study, microarray results from 403 kidney transplant biopsies ( 35 with a diagnosis of TCMR) were used to derive a classifier that assigned TCMR scores to all biopsies; scores were then compared with the histologic diagnosis of the biopsies [25]. Molecular scores correlated with histologic lesions of TCMR (tubulitis and interstitial infiltration) with an accuracy of 89 percent. The positive predictive value (PPV) and negative predictive value (NPV) of a high TCMR molecular score $(\geq 0.1)$ for predicting the histologic diagnosis of TCMR were 62 and 92 percent, respectively. In a parallel study from the same group, microarray results from the same 403 kidney transplant biopsies (56 with a histologic/donor-specific antibody (DSA) diagnosis of ABMR) were used to derive a classifier that assigned ABMR scores to all biopsies $[19,27]$. A positive ABMR molecular score $(\geq 0.2)$ had a PPV and NPV of 64 and 91 percent, respectively, for predicting the histologic/DSA diagnosis of ABMR. In addition, ABMR molecular scores were strongly associated with DSA positivity and were an independent predictor of graft failure. The performance of the TCMR and ABMR molecular scoring systems was prospectively evaluated in a multicenter study of 300 kidney transplant biopsies from 264 patients [28]. Histologic diagnoses of TCMR or ABMR (including C4d-positive ABMR, C4d-negative ABMR and mixed ABMR and TCMR rejection) were present in 11 and 15 percent of biopsies, respectively. A TCMR molecular score of $\geq 0.1$ predicted the histologic diagnosis of TCMR (including borderline rejection) with a PPV and NPV of 49 and 94 percent, respectively. Similarly, an ABMR molecular score of $\geq 0.2$ predicted the diagnosis of ABMR or mixed rejection with PPV and NPV of 50 and 94 percent, respectively. A positive ABMR score in late biopsies (performed more than 1 year post-transplant) was significantly associated with death-censored graft loss at three years (hazard ratio (HR) 2.93, 95\% CI 1.97-4.36).

Invasive biomarkers, though crucial in determining an accurate diagnosis, are subject to variability in sampling and interpretation and more often are utilized when the disease process may have reached an irreversible state.

\section{Non-Invasive Biomarkers}

\subsection{Blood}

\subsubsection{Donor-Specific Antibodies}

The presence of DSAs remains one of the most important biomarkers in the diagnosis of ABMR as defined by the Banff criteria [22]. Many studies have demonstrated that DSAs can not only cause ABMR but are associated with poor long-term allograft survival $[29,30]$. Though techniques to identify DSAs using Luminex bead assays have increased the sensitivity of their detection, their clinical relevance in predicting onset of ABMR or allograft survival remains unclear [31,32]. Since complement binding of antibodies is a critical step in promoting complement-induced allograft injury, the ability of a DSA to bind to complement has been assessed as a tool to predict their pathogenic significance [33]. Multiple single-center studies in adults and pediatric kidney transplant recipients have shown the association of C3d and C1q binding of DSA to be associated with the risk of ABMR and allograft survival [34-37]. However, they also show that high MFI value non-complement-fixing DSAs correlate with risk of ABMR and graft loss just as well [38]. Other investigators have not demonstrated the independent association of C3d and C1q fixation with rejection and graft loss [39-41]. The intra-graft homing ability of a DSA has also been suggested as a potential marker of its pathogenicity [42,43]. Whether the routine use of studying complement fixation and detecting intra-graft DSA is feasible or will change clinical outcomes remains to be studied further.

\subsubsection{Donor-Derived Cell Free DNA}

New biomarkers, such as dd-cfDNA, are being developed to overcome the difficulties of detecting the earliest stages of kidney transplant dysfunction and rejection. Although 
histology obtained via needle biopsy remains the gold standard for diagnosis of rejection, dd-cfDNA serves as an alternative to the invasive renal allograft biopsy and has evolved to a frequently used tool for surveillance and diagnosing of kidney transplant rejection, as well as monitoring of therapy [44-47]. It is known that histological changes and tissue injury from rejection precedes elevation in serum creatinine by several months [32,48]. During allograft rejection, large amounts of dd-cfDNA are released from the injured allograft into the bloodstream [49]. Methods for measuring dd-cfDNA, including quantitative reverse transcription polymerase chain reaction (PCR) [50], droplet digital PCR [51] and targeted next-generation sequencing [44], were looked at in 102 kidney transplant recipients and correlated with allograft rejection status as determined by renal allograft biopsy [44]. The dd-cfDNA level was able to differentiate between biopsy specimens showing any form of rejection (TCMR or ABMR) and those without rejection. Using a cutoff of 1.0 percent, dd-cfDNA had a PPV and NPV for active rejection of 61 and 84 percent, respectively [44]. Accurate and timely detection of kidney transplant rejection and effective treatment are essential for long-term survival of renal allografts. Up until now, the standard of care was that patients with an elevated plasma dd-cfDNA level commonly underwent a renal allograft biopsy to confirm the presence and type of rejection. There are certain limitations to this biomarker which include patients with multiorgan transplants, pregnant patients and patients with active kidney infection. It is important to point out that dd-cfDNA does not differentiate between TCR and ABMR.

\subsubsection{Peripheral Blood Gene Expression Profiling}

Routine surveillance (protocol) biopsies have been used in some centers to monitor patients with stable renal function following kidney transplantation, but these are expensive, invasive, pose significant logistical issues and are subject to variability of interpretation, thus limiting wider application. The current standard of care in monitoring patients following kidney transplantation ranges from not using surveillance biopsies at all, using them only in patients at high immunologic risk, to routine use (protocol biopsies) in all patients. Subclinical acute rejection (subAR) is the presence of histological features of acute rejection on renal biopsy in the absence of a decline in renal function. SubAR is present in approximately $25 \%$ of surveillance biopsies in renal transplant recipients with stable renal function [52]. Therefore, roughly $75 \%$ of surveillance biopsies could be avoided if there was a validated and reliable biomarker test that would distinguish patients with stable renal function who had a quiescent immune profile from those with immune activation.

The TruGraf assay was developed to rule out subclinical rejection in patients with otherwise stable allograft function. Unlike surveillance biopsies which are invasive, it is a DNA microarray-based gene expression blood test that can be obtained easily [53]. The test is based on the analysis of gene-expression "signatures" in peripheral blood that can differentiate a state of immune quiescence, indicating an adequate state of immunosuppression, referred to as transplant excellence (TX), from not-TX, an indication of suboptimal immunosuppression or immune activation. The aim of the TruGraf test is to assist the physician in the assessment of whether the current level of immunosuppression is adequate and to help guide a personalized treatment plan, thereby protecting the function and prolonging graft survival in each individual patient. In the study by Friedewald et al., 192 patients were evaluated across seven sites; the NPV of the test was 91 and $89 \%$ in patients with clinical and biopsy-proven phenotypes and in stable patients with biopsy-proven phenotypes, respectively. The PPV of the test was $48 \%$ in both groups of the study. The TruGraf test has similar limitations to dd-cfDNA, which include multiorgan transplant recipients, pregnant patients and patients with active kidney infection. How the test performs in patients with graft dysfunction has not been assessed and remains to be studied.

\subsubsection{Non-HLA Antibodies}

Non-HLA antibodies directed against endothelial receptors play an important role in allograft vascular injury. Lefaucheur et al. showed in a prospective cohort study of 
1845 patients that participants with anti-angiotensin II type 1-receptor antibodies (AT1RAbs)-associated rejection had a higher prevalence of hypertension and more vascular rejection with arterial inflammation [54]. Other studies in adults and pediatric recipients have also shown that AT1R-Abs are associated with an increased risk of allograft loss and a higher incidence of ABMR [54-57]. Studies across different populations and age groups have determined the cutoff value for AT1R titers in relation to ABMR from 9 to $10 \mathrm{U} / \mathrm{mL}$ [56-60]. AT1R-Abs can be considered a non-invasive prognostic tool to enhance the predictive value of histopathology showing features of ABMR to identify patients at risk of accelerated allograft failure.

Like AT1R-Ab, Banasik et al. have shown that anti-ETAR (endothelin 1 type A receptor) antibody is associated with worse graft function at 12 months post-transplant and with more cases of vasculopathy or arteritis in a series of 116 patients [61]. There is growing recognition of the role played by endothelial cell injury in chronic allograft rejection and ABMR. Investigators are looking at anti-endothelial cell antibodies (AECAs) including anti-major histocompatibility complex I antibody (MICA), anti-vimentin, antibodies to endoglin, LG-3 (perlecan), FLT-3, EBIL-3, ICAM-4 and KTR-1 and antibodies to polymorphic proteins [62-66]. Delville et al. developed and performed a unique endothelial cell crossmatch with sera of highly sensitized patients. Using proteomics and transcriptomics they identified new targets of non-HLA antibodies [67]. Undoubtedly, advances in transplant "omics" will help differentiate pathogenic and injurious non-HLA antibodies and develop targeted therapeutics to address the challenging clinical dilemma of non-HLA-mediated ABMR [67].

\subsubsection{Peripheral Blood Gene/mRNA Arrays}

With the arrival of high throughput sequencing and microarray technologies, the ability to perform molecular assays from peripheral blood has created new possibilities for non-invasive biomarkers in transplantation. The authors of the multicenter prospective BIOMARGIN study identified an eight gene assay with a ROC AUC of $79.9 \%$, to diagnose acute antibody-mediated rejection [68], which has not been validated independently yet.

The authors of the AART study (The Assessment of Acute Rejection in Renal Transplant) developed a 17-gene panel using quantitative PCR from peripheral blood samples called kSORT (Kidney Solid Organ Response Test). kSORT accurately predicted the risk and prevalence of acute rejection with an AUC (area under curve) of 0.92 and a PPV of 93.21\% [69]. However, the follow up large retrospective multicenter study conducted to assess the diagnostic performance of KSORT in a real-world setting failed to validate the biomarker [70]. This demonstrates the challenges of implementing biomarkers in the clinical scenario, which requires thorough independent validation.

\subsection{Urine}

Non-invasive and effortless to obtain serially, the urine sample as a source of biomarker has endless potential. The chemokines CXCL9 and CXCL10, when measured in urine, have been shown to serve as a surrogate for non-invasively measuring intra-graft IFN $\gamma$ expression. Rabant et al. showed that combining urinary CXCL10: Cr ratio with detectable DSA significantly improved the accuracy of diagnosing ABMR non-invasively [71]. Urinary CXCL9 and the CXCL9:Cr ratio were mainly associated with tubulointerstitial inflammation, whereas CXCL10 and the CXCL10:Cr ratio were mainly associated with peritubular capillaritis. Of note, though the PPV was low at 25\%, urinary CXCL10 and the CXCL10:Cr ratio were strongly associated with ABMR, with $>90 \% \mathrm{NPV}$, and may have clinical utility to monitor immunologic quiescence [72].

Utilizing urinary transcriptomics has led to the identification and profiling of distinct mRNA signatures in the urine that are associated with allograft injury [73]. Measurement of mRNA, microRNA and exosomal mRNA in the urine have led to the exciting developments of non-invasive tools to predict allograft rejection [73,74]. Urinary proteomics has also emerged as a potential pathway to discover molecular patterns for detection of ABMR [75]. 


\section{Conclusions}

The onset of active or chronic ABMR plays a major role in determining the long-term survival of an allograft. It is an exciting era to have a diverse array of predictive and diagnostic biomarkers currently under investigation. Although currently the majority of these tools are not widely available or validated, it is possible that a search for a better diagnostic tool may uncover novel therapeutic options as well. For now, histological examination of the kidney remains the current gold standard for diagnosis of acute rejection, especially in the setting of elevated creatinine. The emergence of a non-invasive, highly sensitive and specific biomarker, or combination of biomarkers, that is independently validated in randomized controlled trials and/or serves as a surrogate for long-term graft survival is eagerly awaited by the transplant community.

Author Contributions: S.K.; conceptualization and writing—original draft preparation, Y.K.; conceptualization and writing-original draft preparation. All authors have read and agreed to the published version of the manuscript.

Funding: This research received no external funding.

Institutional Review Board Statement: Not applicable.

Informed Consent Statement: Not applicable.

Data Availability Statement: Not applicable.

Acknowledgments: The authors are grateful to Michelle Josephson MD and Patrick Cunningham MD for their feedback on earlier version of this manuscript. We also thank Servier Medical Art for the use of vector images.

Conflicts of Interest: The authors declare no conflict of interest.

\section{References}

1. OPTN Kidney Kaplan Meier Patient Survival Rates for Transplants Performed: 2008-2015: OPTN/ HRSA; 2021 [Updated Based on OPTN data as of 26 February 2021]. Available online: https://optn.transplant.hrsa.gov/data/view-data-reports/national-data/ (accessed on 26 February 2021).

2. Poggio, E.D.; Augustine, J.J.; Arrigain, S.; Brennan, D.C.; Schold, J.D. Long Term Kidney Transplant Graft Survival-Making Progress When Most Needed. Am. J. Transplant. 2020. [CrossRef]

3. Clayton, P.A.; McDonald, S.P.; Russ, G.R.; Chadban, S.J. Long-Term Outcomes after Acute Rejection in Kidney Transplant Recipients: An ANZDATA Analysis. J. Am. Soc. Nephrol. 2019, 30, 1697-1707. [CrossRef]

4. Halloran, P.F.; Chang, J.; Famulski, K.; Hidalgo, L.G.; Salazar, I.D.; Lopez, M.M.; Matas, A.; Picton, M.; De Freitas, D.; Bromberg, J.; et al. Disappearance of T Cell-Mediated Rejection Despite Continued Antibody-Mediated Rejection in Late Kidney Transplant Recipients. J. Am. Soc. Nephrol. 2014, 26, 1711-1720. [CrossRef] [PubMed]

5. Sellarés, J.; De Freitas, D.G.; Mengel, M.; Reeve, J.; Einecke, G.; Sis, B.; Hidalgo, L.G.; Famulski, K.; Matas, A.; Halloran, P.F. Understanding the Causes of Kidney Transplant Failure: The Dominant Role of Antibody-Mediated Rejection and Nonadherence. Am. J. Transplant. 2011, 12, 388-399. [CrossRef] [PubMed]

6. Aubert, O.; Loupy, A.; Hidalgo, L.; Van Huyen, J.-P.D.; Higgins, S.; Viglietti, D.; Jouven, X.; Glotz, D.; Legendre, C.; Lefaucheur, C.; et al. Antibody-Mediated Rejection Due to Preexisting versusDe NovoDonor-Specific Antibodies in Kidney Allograft Recipients. J. Am. Soc. Nephrol. 2017, 28, 1912-1923. [CrossRef]

7. El-Zoghby, Z.M.; Stegall, M.D.; Lager, D.J.; Kremers, W.K.; Amer, H.; Gloor, J.M.; Cosio, F.G. Identifying Specific Causes of Kidney Allograft Loss. Am. J. Transplant. 2009, 9, 527-535. [CrossRef] [PubMed]

8. Einecke, G.; Sis, B.; Reeve, J.; Mengel, M.; Campbell, P.M.; Hidalgo, L.G.; Kaplan, B.; Halloran, P.F. Antibody-Mediated Microcirculation Injury Is the Major Cause of Late Kidney Transplant Failure. Am. J. Transplant. 2009, 9, 2520-2531. [CrossRef]

9. Gaston, R.S.; Cecka, J.M.; Kasiske, B.L.; Fieberg, A.M.; LeDuc, R.; Cosio, F.C.; Gourishankar, S.; Grande, J.; Halloran, P.; Hunsicker, L.; et al. Evidence for Antibody-Mediated Injury as a Major Determinant of Late Kidney Allograft Failure. Transplantation 2010, 90, 68-74. [CrossRef]

10. Hidalgo, L.; Campbell, P.; Sis, B.; Einecke, G.; Mengel, M.; Chang, J.; Sellares, J.; Reeve, J.; Halloran, P. De novo donor-Specific antibody at the time of kidney transplant biopsy associates with microvascular pathology and late graft failure. Am. J. Transplant. 2009, 9, 2532-2541. [CrossRef]

11. Loupy, A.; Hill, G.S.; Jordan, S.C. The impact of donor-specific anti-HLA antibodies on late kidney allograft failure. Nat. Rev. Nephrol. 2012, 8, 348-357. [CrossRef]

12. Loupy, A.; Lefaucheur, C. Antibody-Mediated Rejection of Solid-Organ Allografts. N. Engl. J. Med. 2018, 379, 1150-1160. [CrossRef] [PubMed] 
13. Loupy, A.; Suberbielle-Boissel, C.; Hill, G.; Lefaucheur, C.; Anglicheau, D.; Zuber, J.; Martinez, F.; Thervet, E.; Méjean, A.; Charron, D. Outcome of subclinical antibody-Mediated rejection in kidney transplant recipients with preformed donor-Specific antibodies. Am. J. Transplant. 2009, 9, 2561-2570. [CrossRef] [PubMed]

14. Loupy, A.; Hill, G.; Suberbielle, C.; Charron, D.; Anglicheau, D.; Zuber, J.; Timsit, M.; Duong, J.; Bruneval, P.; Vernerey, D. Significance of C4d Banff scores in early protocol biopsies of kidney transplant recipients with preformed donor-Specific antibodies (DSA). Am. J. Transplant. 2011, 11, 56-65. [CrossRef] [PubMed]

15. Furness, P.N.; Taub, N.; Convergence of European Renal Transplant Pathology Assessment Procedures (CERTPAP) Project. International variation in the interpretation of renal transplant biopsies: Report of the CERTPAP Project. Kidney Int. 2001, 60, 1998-2012. [CrossRef] [PubMed]

16. Ortiz, F.; Gelpi, R.; Helanterä, I.; Melilli, E.; Honkanen, E.; Bestard, O.; Grinyo, J.M.; Cruzado, J.M. Decreased Kidney Graft Survival in Low Immunological Risk Patients Showing Inflammation in Normal Protocol Biopsies. PLoS ONE 2016, 11, e0159717. [CrossRef] [PubMed]

17. Erpicum, P.; Hanssen, O.; Weekers, L.; Lovinfosse, P.; Meunier, P.; Tshibanda, L.; Krzesinski, J.-M.; Hustinx, R.; Jouret, F. Noninvasive approaches in the diagnosis of acute rejection in kidney transplant recipients, part II: Omics analyses of urine and blood samples. Clin. Kidney J. 2016, 10, 106-115. [CrossRef] [PubMed]

18. Anglicheau, D.; Naesens, M.; Essig, M.; Gwinner, W.; Marquet, P. Establishing biomarkers in transplant medicine: A critical review of current approaches. Transplantation 2016, 100, 2024-2038. [CrossRef]

19. Dharnidharka, V.R.; Malone, A. Biomarkers to detect rejection after kidney transplantation. Pediatr. Nephrol. 2017, 33, 1113-1122. [CrossRef]

20. Solez, K.; Axelsen, R.A.; Benediktsson, H.; Burdick, J.F.; Cohen, A.H.; Colvin, R.B.; Croker, B.P.; Droz, D.; Dunnill, M.S.; Halloran, P.F.; et al. International standardization of criteria for the histologic diagnosis of renal allograft rejection: The Banff working classification of kidney transplant pathology. Kidney Int. 1993, 44, 411-422. [CrossRef]

21. Racusen, L.C.; Solez, K.; Colvin, R.B.; Bonsib, S.M.; Castro, M.C.; Cavallo, T.; Croker, B.P.; Demetris, A.J.; Drachenberg, C.B.; Fogo, A.B.; et al. The Banff 97 working classification of renal allograft pathology. Kidney Int. 1999, 55, 713-723. [CrossRef]

22. Haas, M.; Loupy, A.; Lefaucheur, C.; Roufosse, C.; Glotz, D.; Seron, D.; Nankivell, B.; Halloran, P.; Colvin, R.; Akalin, E. The Banff 2017 Kidney Meeting Report: Revised Diagnostic Criteria for Chronic Active T Cell-Mediated Rejection, Antibody-Mediated Rejection, and Prospects for Integrative Endpoints for Next_Generation Clinical Trials; Wiley Online Library: Hoboken, NJ, USA, 2018.

23. Halloran, P.F.; Famulski, K.S.; Reeve, P.F.H.K.S.F.J. Molecular assessment of disease states in kidney transplant biopsy samples. Nat. Rev. Nephrol. 2016, 12, 534-548. [CrossRef] [PubMed]

24. Strom, T.B.; Suthanthiran, M. Transcriptional profiling to assess the clinical status of kidney transplants. Nat. Clin. Pract. Nephrol. 2006, 2, 116-117. [CrossRef] [PubMed]

25. Reeve, J.; Sellarés, J.; Mengel, M.; Sis, B.; Skene, A.; Hidalgo, L.; De Freitas, D.; Famulski, K.; Halloran, P. Molecular diagnosis of T cell-Mediated rejection in human kidney transplant biopsies. Am. J. Transplant. 2013, 13, 645-655. [CrossRef]

26. Venner, J.; Famulski, K.; Badr, D.; Hidalgo, L.; Chang, J.; Halloran, P. Molecular Landscape of T Cell-Mediated Rejection in Human Kidney Transplants: Prominence of CTLA4 and PD Ligands. Am. J. Transplant. 2014, 14, 2565-2576. [CrossRef] [PubMed]

27. Sellarés, J.; Reeve, J.; Loupy, A.; Mengel, M.; Sis, B.; Skene, A.; De Freitas, D.; Kreepala, C.; Hidalgo, L.; Famulski, K. Molecular diagnosis of antibody-Mediated rejection in human kidney transplants. Am. J. Transplant. 2013, 13, 971-983. [CrossRef]

28. Halloran, P.; Pereira, A.; Chang, J.; Matas, A.; Picton, M.; De Freitas, D.; Bromberg, J.; Serón, D.; Sellarés, J.; Einecke, G. Potential impact of microarray diagnosis of $\mathrm{T}$ cell-mediated rejection in kidney transplants: The INTERCOM study. Am. J. Transplant. 2013, 13, 2352-2363. [CrossRef] [PubMed]

29. Willicombe, M.; Brookes, P.; Sergeant, R.; Santos-Nunez, E.; Steggar, C.; Galliford, J.; Mclean, A.; Cook, T.H.; Cairns, T.; Roufosse, C. De novo DQ donor-Specific antibodies are associated with a significant risk of antibody-mediated rejection and transplant glomerulopathy. Transplantation 2012, 94, 172-177. [CrossRef] [PubMed]

30. Ginevri, F.; Nocera, A.; Comoli, P.; Innocente, A.; Cioni, M.; Parodi, A.; Fontana, I.; Magnasco, A.; Nocco, A.; Tagliamacco, A. Posttransplant de novo donor-Specific HLA antibodies identify pediatric kidney recipients at risk for late antibody-Mediated rejection. Am. J. Transplant. 2012, 12, 3355-3362. [CrossRef] [PubMed]

31. Mohan, S.; Palanisamy, A.; Tsapepas, D.; Tanriover, B.; Crew, R.J.; Dube, G.; Ratner, L.E.; Cohen, D.J.; Radhakrishnan, J. Donor-Specific Antibodies Adversely Affect Kidney Allograft Outcomes. J. Am. Soc. Nephrol. 2012, 23, 2061-2071. [CrossRef]

32. Wiebe, C.; Gibson, I.; Blydt-Hansen, T.; Karpinski, M.; Ho, J.; Storsley, L.; Goldberg, A.; Birk, P.; Rush, D.; Nickerson, P. Evolution and clinical pathologic correlations of de novo donor-Specific HLA antibody post kidney transplant. Am. J. Transplant. 2012, 12, 1157-1167. [CrossRef]

33. Loupy, A.; Lefaucheur, C.; Vernerey, D.; Prugger, C.; Van Huyen, J.-P.D.; Mooney, N.; Suberbielle, C.; Frémeaux-Bacchi, V.; Méjean, A.; Desgrandchamps, F.; et al. Complement-Binding Anti-HLA Antibodies and Kidney-Allograft Survival. N. Engl. J. Med. 2013, 369, 1215-1226. [CrossRef]

34. Lee, H.; Han, E.; Choi, A.-R.; Ban, T.H.; Chung, B.H.; Yang, C.W.; Choi, Y.J.; Oh, E.-J. Clinical impact of complement (C1q, C3d) binding De Novo donor-specific HLA antibody in kidney transplant recipients. PLoS ONE 2018, 13, e0207434. [CrossRef]

35. Bailly, E.; Anglicheau, D.; Blancho, G.; Gatault, P.; Vuiblet, V.; Chatelet, V.; Morelon, E.; Malvezzi, P.; Parissiadis, A.; Tourret, J. Prognostic value of the persistence of C1q-binding anti-HLA antibodies in acute antibody-mediated rejection in kidney transplantation. Transplantation 2018, 102, 688-698. [CrossRef] 
36. Lee, D.; Kim, B.; Kim, J.; Kim, I.; Jeon, M. (Eds.) C3d-binding donor-specific hla antibody is associated with a high risk of antibody-mediated rejection and graft loss in stable kidney transplant recipients: A single-center cohort study. In Transplantation Proceedings; Elsevier: Amsterdam, The Netherlands, 2018.

37. Hayde, N.; Solomon, S.; Caglar, E.; Ge, J.; Qama, E.; Colovai, A. C1q-Binding DSA and allograft outcomes in pediatric kidney transplant recipients. Pediatr. Transplant. 2021, 25, e13885. [CrossRef]

38. Gebel, H.M.; Bray, R.A. A diagnostic 'C' saw: The ups and downs of C1q testing. Curr. Opin. Organ Transplant. 2019, 24, 402-410. [CrossRef]

39. Courant, M.; Visentin, J.; Linares, G.; Dubois, V.; Lepreux, S.; Guidicelli, G.; Thaunat, O.; Merville, P.; Couzi, L.; Taupin, J.-L. The disappointing contribution of anti-human leukocyte antigen donor-specific antibodies characteristics for predicting allograft loss Nephrol. Dial. Transplant. 2018, 33, 1853-1863. [CrossRef] [PubMed]

40. Vargas, G.G.; Olagne, J.; Parissiadis, A.; Joly, M.; Cognard, N.; Perrin, P.; Froelich, N.; Guntz, P.; Gachet, C.; Moulin, B. Does a Useful Test Exist to Properly Evaluate the Pathogenicity of Donor-specific Antibodies? Lessons from a Comprehensive Analysis in a Well-studied Single-center Kidney Transplant Cohort. Transplantation 2019, 104, 2148-2157. [CrossRef] [PubMed]

41. Eskandary, F.; Bond, G.; Kozakowski, N.; Regele, H.; Marinova, L.; Wahrmann, M.; Kikic, Ž.; Haslacher, H.; Rasoul-Rockenschaub, S.; Kaltenecker, C.C. Diagnostic contribution of donor-specific antibody characteristics to uncover late silent antibody-mediated rejection-Results of a cross-sectional screening study. Transplantation 2017, 101, 631-641. [CrossRef] [PubMed]

42. Nocera, A.; Tagliamacco, A.; Cioni, M.; Innocente, A.; Fontana, I.; Barbano, G.; Carrea, A.; Ramondetta, M.; Sementa, A.; Basso, S. Kidney intragraft homing of de novo donor-Specific HLA antibodies is an essential step of antibody-Mediated damage but not per se predictive of graft loss. Am. J. Transplant. 2017, 17, 692-702. [CrossRef] [PubMed]

43. Bachelet, T.; Couzi, L.; Lepreux, S.; Legeret, M.; Pariscoat, G.; Guidicelli, G.; Merville, P.; Taupin, J.L. Kidney intragraft donorSpecific antibodies as determinant of antibody-Mediated lesions and poor graft outcome. Am. J. Transplant. 2013, 13, 2855-2864. [CrossRef]

44. Bloom, R.D.; Bromberg, J.S.; Poggio, E.D.; Bunnapradist, S.; Langone, A.J.; Sood, P.; Matas, A.J.; Mehta, S.; Mannon, R.B.; Sharfuddin, A.; et al. Cell-Free DNA and Active Rejection in Kidney Allografts. J. Am. Soc. Nephrol. 2017, 28, $2221-2232$. [CrossRef] [PubMed]

45. Beck, J.; Oellerich, M.; Schulz, U.; Schauerte, V.; Reinhard, L.; Fuchs, U.; Knabbe, C.; Zittermann, A.; Olbricht, C.; Gummert, J.; et al. Donor-Derived Cell-Free DNA Is a Novel Universal Biomarker for Allograft Rejection in Solid Organ Transplantation. Transplant. Proc. 2015, 47, 2400-2403. [CrossRef]

46. Stites, E.; Kumar, D.; Olaitan, O.; John Swanson, S.; Leca, N.; Weir, M.; Bromberg, J.; Melancon, J.; Agha, I.; Fattah, H.; et al. High levels of dd-cfDNA identify patients with TCMR 1A and borderline allograft rejection at elevated risk of graft injury. Am. J. Transplant. 2020, 20, 2491-2498. [CrossRef]

47. Oellerich, M.; Shipkova, M.; Asendorf, T.; Walson, P.D.; Schauerte, V.; Mettenmeyer, N.; Kabakchiev, M.; Hasche, G.; Grone, H.J.; Friede, T.; et al. Absolute quantification of donor-derived cell-free DNA as a marker of rejection and graft injury in kidney transplantation: Results from a prospective observational study. Am. J. Transplant. 2019, 19, 3087-3099. [CrossRef]

48. Djamali, A.; Kaufman, D.B.; Ellis, T.M.; Zhong, W.; Matas, A.; Samaniego, M. Diagnosis and management of antibody-mediated rejection: Current status and novel approaches. Am. J. Transplant. 2014, 14, 255-271. [CrossRef] [PubMed]

49. Moreira, V.G.; García, B.P.; Martín, J.M.B.; Suárez, F.O.; Alvarez, F.V. Cell-Free DNA as a Noninvasive Acute Rejection Marker in Renal Transplantation. Clin. Chem. 2009, 55, 1958-1966. [CrossRef]

50. LO, Y.D.; TEIN, M.C.; PANG, C.P.; Yeung, C.K.; Tong, K.-L. Presence of donor-specific DNA in plasma of kidney and livertransplant recipients. Lancet 1998, 351, 1329-1330. [CrossRef]

51. Beck, J.; Bierau, S.; Balzer, S.; Andag, R.; Kanzow, P.; Schmitz, J.; Gaedcke, J.; Moerer, O.; Slotta, J.E.; Walson, P.; et al. Digital Droplet PCR for Rapid Quantification of Donor DNA in the Circulation of Transplant Recipients as a Potential Universal Biomarker of Graft Injury. Clin. Chem. 2013, 59, 1732-1741. [CrossRef]

52. Loupy, A.; Vernerey, D.; Tinel, C.; Aubert, O.; Van Huyen, J.-P.D.; Rabant, M.; Verine, J.; Nochy, D.; Empana, J.-P.; Martinez, F.; et al. Subclinical Rejection Phenotypes at 1 Year Post-Transplant and Outcome of Kidney Allografts. J. Am. Soc. Nephrol. 2015, 26, 1721-1731. [CrossRef]

53. Marsh, C.; Kurian, S.; Rice, J.; Whisenant, T.; David, J.; Rose, S.; Schieve, C.; Lee, D.; Case, J.; Barrick, B. (Eds.) Application of TruGraf v1: A novel molecular biomarker for managing kidney transplant recipients with stable renal function. In Transplantation Proceedings; Elsevier: Amsterdam, The Netherlands, 2019.

54. Lefaucheur, C.; Viglietti, D.; Bouatou, Y.; Philippe, A.; Pievani, D.; Aubert, O.; Van Huyen, J.-P.D.; Taupin, J.-L.; Glotz, D.; Legendre, C.; et al. Non-HLA agonistic anti-angiotensin II type 1 receptor antibodies induce a distinctive phenotype of antibody-mediated rejection in kidney transplant recipients. Kidney Int. 2019, 96, 189-201. [CrossRef] [PubMed]

55. Sas-Strózik, A.; Donizy, P.; Kościelska-Kasprzak, K.; Kamińska, D.; Gawlik, K.; Mazanowska, O.; Madziarska, K.; Hałoń, A.; Krajewska, M.; Banasik, M. (Eds.) Angiotensin II type 1 receptor expression in renal transplant biopsies and anti-AT1R antibodies in serum indicates the risk of transplant loss. In Transplantation Proceedings; Elsevier: Amsterdam, The Netherlands, 2020.

56. Fichtner, A.; Süsal, C.; Schröder, C.; Höcker, B.; Rieger, S.; Waldherr, R.; Westhoff, J.H.; Sander, A.; Dragun, D.; Tönshoff, B. Association of angiotensin II type 1 receptor antibodies with graft histology, function and survival in paediatric renal transplant recipients. Nephrol. Dial. Transplant. 2018, 33, 1065-1072. [CrossRef] 
57. Banasik, M.; Boratyńska, M.; Kościelska-Kasprzak, K.; Kamińska, D.; Bartoszek, D.; Żabińska, M.; Myszka, M.; Zmonarski, S.; Protasiewicz, M.; Nowakowska, B.; et al. The influence of non-HLA antibodies directed against angiotensin II type 1 receptor (AT1R) on early renal transplant outcomes. Transpl. Int. 2014, 27, 1029-1038. [CrossRef]

58. Giral, M.; Foucher, Y.; Dufay, A.; Van Huyen, J.D.; Renaudin, K.; Moreau, A.; Philippe, A.; Hegner, B.; Dechend, R.; Heidecke, H. Pretransplant sensitization against angiotensin II type 1 receptor is a risk factor for acute rejection and graft loss. Am. J. Transplant. 2013, 13, 2567-2576. [CrossRef] [PubMed]

59. Lee, J.; Huh, K.H.; Park, Y.; Park, B.G.; Yang, J.; Jeong, J.C.; Lee, J.; Park, J.B.; Cho, J.-H.; Lee, S.; et al. The clinicopathological relevance of pretransplant anti-angiotensin II type 1 receptor antibodies in renal transplantation. Nephrol. Dial. Transplant. 2015, 32, 1244-1250. [CrossRef]

60. Taniguchi, M.; Rebellato, L.; Cai, J.; Hopfield, J.; Briley, K.; Haisch, C.; Catrou, P.; Bolin, P.; Parker, K.; Kendrick, W. Higher risk of kidney graft failure in the presence of anti-Angiotensin II type-1 receptor antibodies. Am. J. Transplant. 2013, 13, $2577-2589$. [CrossRef]

61. Banasik, M.; Boratyńska, M.; Kościelska-Kasprzak, K.; Krajewska, M.; Mazanowska, O.; Kamińska, D.; Bartoszek, D.; Żabińska, M.; Myszka, M.; Nowakowska, B.; et al. The impact of non-HLA antibodies directed against endothelin-1 type A receptors (ETAR) on early renal transplant outcomes. Transpl. Immunol. 2014, 30, 24-29. [CrossRef] [PubMed]

62. Jackson, A.M.; Delville, M.; Lamarthée, B.; Anglicheau, D. Sensitization to endothelial cell antigens: Unraveling the cause or effect paradox. Hum. Immunol. 2019, 80, 614-620. [CrossRef]

63. Riesco, L.; Irure, J.; Rodrigo, E.; Guiral, S.; Ruiz, J.C.; Gómez, J.; López-Hoyos, M.; Segundo, D.S. Anti-perlecan antibodies and acute humoral rejection in hypersensitized patients without forbidden HLA specificities after kidney transplantation. Transpl. Immunol. 2019, 52, 53-56. [CrossRef]

64. Dieudé, M.; Cardinal, H.; Hébert, M.-J. Injury derived autoimmunity: Anti-perlecan/LG3 antibodies in transplantation. Hum. Immunol. 2019, 80, 608-613. [CrossRef] [PubMed]

65. Dragun, D.; Catar, R.; Philippe, A. Non-HLA antibodies against endothelial targets bridging allo- and autoimmunity. Kidney Int. 2016, 90, 280-288. [CrossRef] [PubMed]

66. Jackson, A.M.; Wiebe, C.; Hickey, M.J. The role of non-HLA antibodies in solid organ transplantation: A complex deliberation. Curr. Opin. Organ Transplant. 2020, 25, 536-542. [CrossRef] [PubMed]

67. Delville, M.; Lamarthée, B.; Pagie, S.; See, S.B.; Rabant, M.; Burger, C.; Gatault, P.; Giral, M.; Thaunat, O.; Arzouk, N. Early acute microvascular kidney transplant rejection in the absence of anti-HLA antibodies is associated with preformed IgG antibodies against diverse glomerular endothelial cell antigens. J. Am. Soc. Nephrol. 2019, 30, 692-709. [CrossRef]

68. Van Loon, E.; Gazut, S.; Yazdani, S.; Lerut, E.; De Loor, H.; Coemans, M.; Noël, L.-H.; Thorrez, L.; Van Lommel, L.; Schuit, F.; et al. Development and validation of a peripheral blood mRNA assay for the assessment of antibody-mediated kidney allograft rejection: A multicentre, prospective study. EBioMedicine 2019, 46, 463-472. [CrossRef] [PubMed]

69. Roedder, S.; Sigdel, T.; Salomonis, N.; Hsieh, S.; Dai, H.; Bestard, O.; Metes, D.; Zeevi, A.; Gritsch, A.; Cheeseman, J.; et al. The kSORT Assay to Detect Renal Transplant Patients at High Risk for Acute Rejection: Results of the Multicenter AART Study. PLoS Med. 2014, 11, e1001759. [CrossRef]

70. Van Loon, E.; Giral, M.; Anglicheau, D.; Lerut, E.; Dubois, V.; Rabeyrin, M.; Brouard, S.; Roedder, S.; Spigarelli, M.G.; Rabant, M. Diagnostic performance of kSORT, a blood-Based mRNA assay for noninvasive detection of rejection after kidney transplantation: A retrospective multicenter cohort study. Am. J. Transplant. 2021, 21, 740-750. [CrossRef] [PubMed]

71. Rabant, M.; Amrouche, L.; Morin, L.; Bonifay, R.; Lebreton, X.; Aouni, L.; Benon, A.; Sauvaget, V.; Le Vaillant, L.; Aulagnon, F. Early Low Urinary CXCL 9 and CXCL 10 Might Predict Immunological Quiescence in Clinically and Histologically Stable Kidney Recipients. Am. J. Transplant. 2016, 16, 1868-1881. [CrossRef]

72. Rabant, M.; Amrouche, L.; Lebreton, X.; Aulagnon, F.; Benon, A.; Sauvaget, V.; Bonifay, R.; Morin, L.; Scemla, A.; Delville, M.; et al. Urinary C-X-C Motif Chemokine 10 Independently Improves the Noninvasive Diagnosis of Antibody-Mediated Kidney Allograft Rejection. J. Am. Soc. Nephrol. 2015, 26, 2840-2851. [CrossRef] [PubMed]

73. Van de Vrie, M.; Deegens, J.; Eikmans, M.; van der Vlag, J.; Hilbrands, L. Urinary microRNA as biomarker in renal transplantation. Am. J. Transplant. 2017, 17, 1160-1166. [CrossRef]

74. El Fekih, R.; Hurley, J.; Tadigotla, V.; Alghamdi, A.; Srivastava, A.; Coticchia, C.; Choi, J.; Allos, H.; Yatim, K.; Alhaddad, J.; et al. Discovery and Validation of a Urinary Exosome mRNA Signature for the Diagnosis of Human Kidney Transplant Rejection. J. Am. Soc. Nephrol. 2021, 32, 994-1004. [CrossRef] [PubMed]

75. Kanzelmeyer, N.K.; Zürbig, P.; Mischak, H.; Metzger, J.; Fichtner, A.; Ruszai, K.H.; Seemann, T.; Hansen, M.; Wygoda, S.; Krupka, K. Urinary proteomics to diagnose chronic active antibody-Mediated rejection in pediatric kidney transplantation-A pilot study. Transpl. Int. 2019, 32, 28-37. [CrossRef] [PubMed] 